\title{
Fatty acid composition of Tilia spp. seed oils
}

\author{
By M.K. Dowd ${ }^{a, *}$ and M.C. Farve ${ }^{a}$ \\ a Southern Regional Research Center, Agricultural Research Service, \\ U.S. Department of Agriculture, 1100 Robert E. Lee Blvd. New Orleans, LA, 70124 USA \\ * Corresponding author: michael.dowd@ars.usda.gov
}

\section{RESUMEN}

Composición en ácidos grasos de aceites de semillas de Tilia spp.

Como parte de un estudio sobre la composición de aceites derivados de semillas de plantas Malvaceae, las semillas de siete especies de Tilia (árboles de tilia o lima) fueron evaluadas con respecto a sus perfiles de ácidos grasos. Las semillas fueron obtenidas de Germplasm Research Information Network así como de varias fuentes comerciales. Tras la extracción del aceite con hexano, los glicéridos fueron trans-metilados y analizados por cromatografía de gases con dos fases polares estacionarias. Todos los aceites extraidos de las semiIlas analizados estaban compuestos principalmente de ácido linoleico (49-60\%) y, en cantidades más bajas de ácido oleico (16-22\%) y palmítico (8-10\%). Otros componentes secundarios típicos también fueron encontrados. Además, los ácidos ciclopropenoides (i.e., ácidos estercúlicos y malválicos) estuvieron presentes en niveles entre 6 y $17 \%$. En todas las muestras, el nivel de ácido malválico fue aproximadamente el doble del nivel de ácido estercúlico, lo que indica que una cantidad considerable de $\alpha$-oxidación del ácido estercúlico ocurrió en las semillas. Dos productos de $\alpha$-oxidación adicionales, los ácidos 8-heptadecenoico y 8,11-heptadecadienoico también fueron determinados. Juntos el nivel de estos ácidos grasos estuvo entre 1.3 y $2.3 \%$, estas cantidades son comparables a los niveles reportados recientemente de estos ácidos en el aceite de semilla de Thespesia populnea.

PALABRAS CLAVE: $\alpha$-oxidación de ácidos grasos Ácidos ciclopropenoides - Árboles de tilia o lima - Árboles de tilia o Linden.

\section{SUMMARY}

\section{Fatty acid composition of Tilia spp. seed oils}

As part of a study of the seed oil fatty acid composition of Malvaceae plants, the seeds of seven Tilia species (lime or linden trees) were evaluated for their fatty acid profiles. Seeds were obtained from the Germplasm Research Information Network and from various commercial sources. After extraction of the seed oil with hexane, the glycerides were trans-methylated and analyzed by gas chromatography on two polar stationary phases. All of the seed oils analyzed were composed primarily of linoleic acid (49-60\%) with lesser amounts of oleic (16-22\%) and palmitic (8-10\%) acids. The usual secondary components were also found. In addition, cyclopropenoid acids (i.e., sterculic and malvalic acids) were present at levels between 6 and $17 \%$. In all samples, the level of malvalic acid was approximately twice the level of sterculic acid, indicating that considerable $\alpha$-oxidation of sterculic acid had occurred in these seeds.
Two additional $\alpha$-oxidation products, 8-heptadecenoic acid and 8,11-heptadecadienoic acid were also detected. Combined, the level of these fatty acids was between 1.3 and $2.3 \%$, roughly comparable to the levels of these acids recently reported in the seed oil of Thespesia populnea.

KEY-WORDS: $\alpha$-Oxidized fatty acids - Cyclopropenoid fatty acids - Lime trees - Linden trees.

\section{INTRODUCTION}

As part of a broad study of the seed oil fatty acid composition of Malvaceae plants, several species within the Tilia genus were evaluated. These trees, commonly referred to as lime, linden, or basswood trees in English, were originally considered as part of the Tiliaceae plant family. Recent genetic analyses, however, have suggested that these plants are better placed into a subfamily (Tilioideae) within a more encompassing Malvaceae family (Alverson, 1999; Bayer 1999).

Reports on the presence of cyclopropeniod fatty acids in the seed oils of the Tilia spp. plants have been variable. Raju and Reiser (1966) reported $T$. platyphyllos seed oil to contain malvalic (cpe18:1) and sterculic (cpe19:1) acids at a combined level of $3.2 \%$. In contrast, other reports on T. platyphyllos and other Tilia spp. seed oils, including one relatively recent report, have not mentioned these acids (Cristea and Stanescu, 1967; Mruk-Łuczkiewicz, 1976; Küsmenoğlu and Toker, 1998). Consequently, it was of interest to confirm the presence of these components in the seed oils of the Tilioideae subfamily. As cpe18:1 is generally accepted as being formed by the $\alpha$-oxidation of cpe19:1 (Yano et al., 1972, Bao et al., 2002) and other $\alpha$-oxidation products have been recently detected in the seeds of Thespesia populnea (Dowd, 2012), also from the Malvaceae family, it was of interest to see if other $\alpha$-oxidation products were also present in these oils.

\section{MATERIALS AND METHODS}

\subsection{Plant material}

Seeds of T. cordata (Samples 1 and 2, accessions 70011 and 70012, respectively) were obtained from 
the Woody Landscape Plant Germplasm Repository (Beltsville, MD, USA). Seeds of $T$. platyphyllos (Sample 1) were obtained from the OMC Seed Store (Jacksonville, FL, USA). T. americana and T. tomentosa (Sample 1) seeds were obtained from Treehelp, LTD (Buffalo, NY, USA). Seeds of $T$. tomentosa (Sample 2) were obtained from G.A. Walter Nursery (Richfield, PA, USA). Seeds of $T$. amurensis, T. mandshurica, T. caucasica (also named $T$. dasystyla subsp. caucasica), $T$. platyphyllos (Sample 2), T. cordata (Sample 3), and T. tomentosa (Sample 3) were obtained from Lawyer Nursery (Plains, MT, USA).

\subsection{Oil recovery and methylation chemistry}

For each sample, hulls were removed by hand and four to five well-formed kernels were sectioned into pieces with a razor blade. Seed pieces were placed in a micro-centrifuge vial with $1 \mathrm{~mL}$ of hexane and two to three 2.3-mm diam. chrome steel balls. Oil was extracted by wet milling the seeds with a BioSpec Bead-Beater 8 bead mill (Bartlesville, OK, USA) operated at $90 \%$ power until the kernel tissue was completely macerated ( 5-10 $\mathrm{min})$. The tubes were then centrifuged to pellet debris, and each miscella was transferred to a screw-cap test tube.

Methyl esters were formed by a base-catalyzed transesterification procedure similar to that previously described (Dowd, 2012). Two hundred microliters of Methanolic base (Supelco, Bellefonte, PA, USA) was added to each recovered miscella, and the mixtures were heated at $70^{\circ} \mathrm{C}$ for $10 \mathrm{~min}$ with periodic vortex mixing. After allowing the tubes to cool, $1 \mathrm{~mL}$ of $\mathrm{NaCl}$-saturated water and $1 \mathrm{~mL}$ of hexane were added to each preparation; the tubes were re-mixed and then allowed to settle into organic and aqueous phases. The organic layers were recovered for analysis by gas chromatography.

To confirm suspicions about the lack of nonesterified short-chain fatty acids in the oils, acidbased esterification was also conducted on a few samples. The oil samples were treated as described above, but with the Methanolic base replaced with $1 \mathrm{~mL}$ of $\mathrm{BF}_{3}$-methanol $(10 \% \mathrm{w} / \mathrm{v})$ (Supelco). Each hexane phase was recovered and was also analyzed by gas chromatography.

\subsection{Gas chromatography}

Two capillary columns were needed to detect all of the methyl esters present. A Supelco SP2380 column $(0.25 \mathrm{~mm}$ i.d. $\times 30 \mathrm{~m} \times 0.20 \mu \mathrm{m}$ film thickness) was able to separate most of the fatty acids of interest, but could not separate the dihydrosterculic acid (cpa19:0) and linoleic acid (9,12-18:2) components (Figure 1). This separation was achieved with a Supelco SP-2560 column $(0.25 \mathrm{~mm}$ i.d. $\times 100 \mathrm{~m} \times 0.20 \mu \mathrm{m}$ film thickness), which itself was not able to separate the heptadecadienoic acid (8,11-17:2) and oleic acid (9-18:1) methyl esters (Figure 2). A pair of Agilent 7890 gas chromatographs was used, each configured with split/splitless injectors and flame ionization detectors. Helium was used as the carrier gas. The injectors were operated at $240^{\circ} \mathrm{C}$ in split mode with a split ratio of 1:100. Injector head pressures were adjusted to yield a linear column

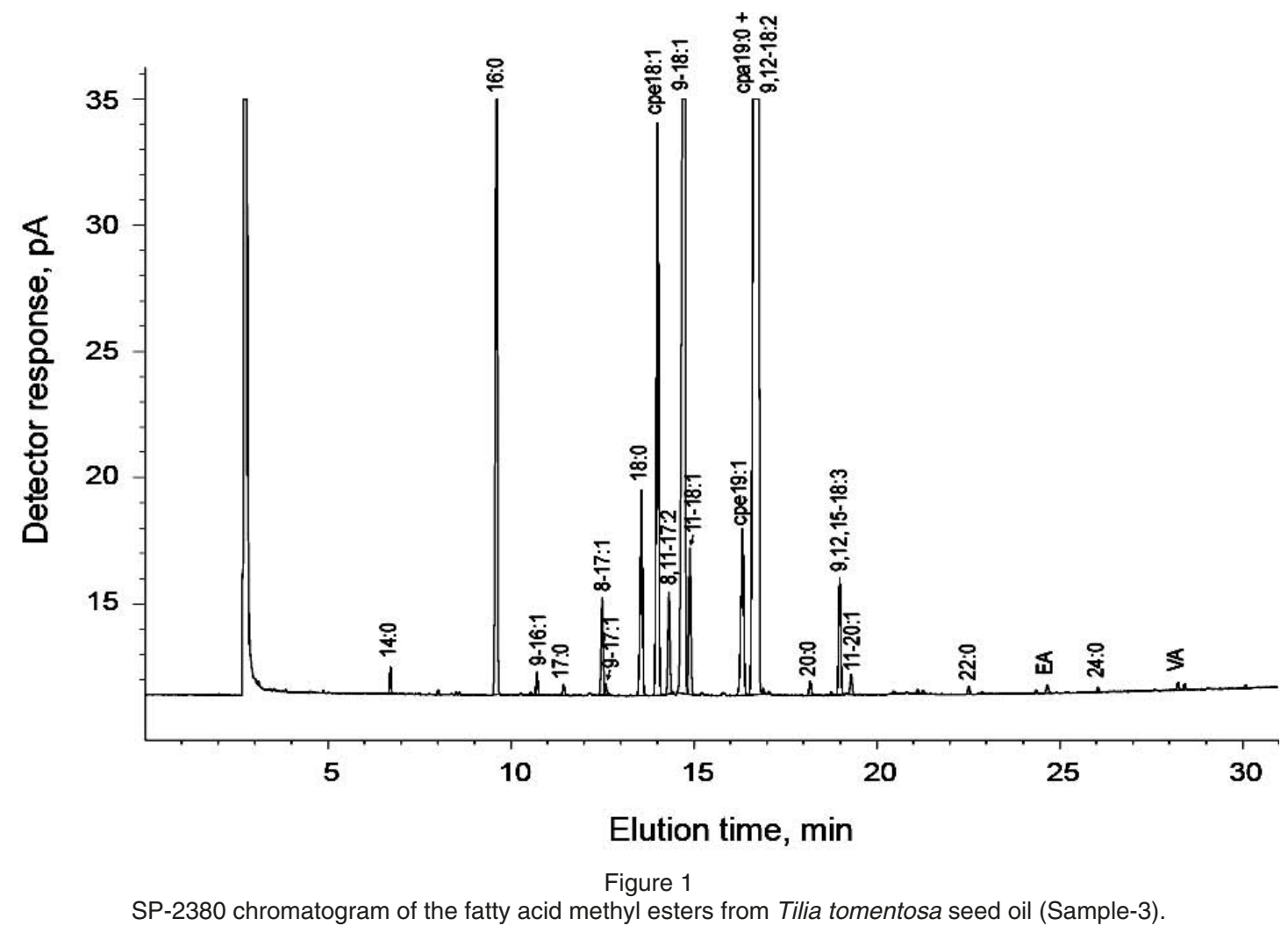




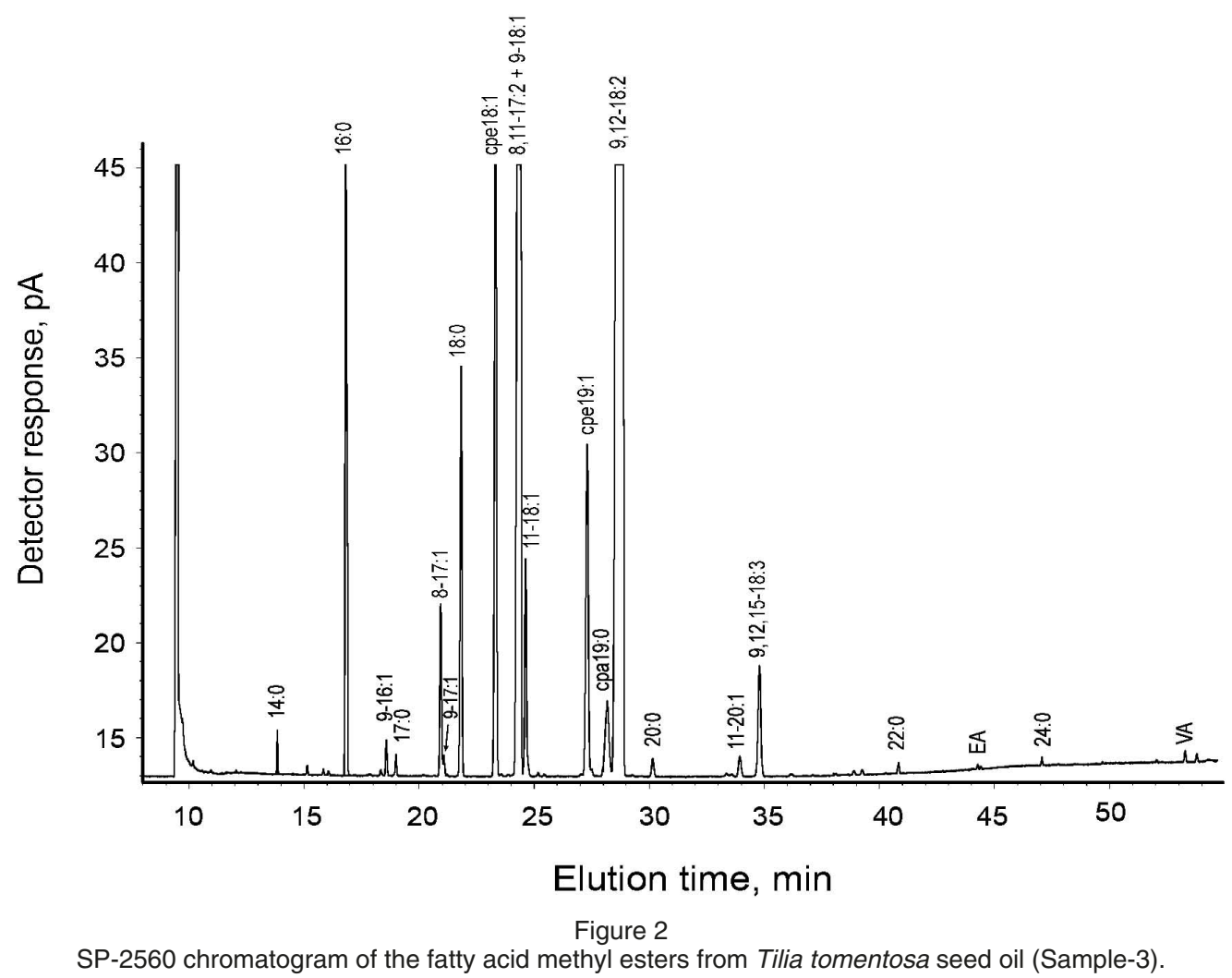

velocity of $\sim 20 \mathrm{~cm} \mathrm{~s}^{-1}$. Detectors were operated at $300^{\circ} \mathrm{C}$. For the runs with the SP-2380 column, the oven temperature program was initiated at $150^{\circ} \mathrm{C}$, held for $3 \mathrm{~min}$; then the temperature was ramped at $2^{\circ} \mathrm{C} \min ^{-1}$ to $180^{\circ} \mathrm{C}$; then ramped at $4{ }^{\circ} \mathrm{C} \min ^{-1}$ to the final temperature of $240^{\circ} \mathrm{C}$, which was held for $15 \mathrm{~min}$. For the work with the SP-2560 column, the oven was set at $180^{\circ} \mathrm{C}$ for $35 \mathrm{~min}$; then the temperature was ramped at $2^{\circ} \mathrm{C} \mathrm{min}^{-1}$ to $240^{\circ} \mathrm{C}$, and held for $15 \mathrm{~min}$.

Identities of the individual fatty acids were determined by comparing elution times with standards and by mass spectrometry of methyl esters and dimethyldisulfide derivatives as previously described (Dowd, 2012). Fatty acid distributions were determined from the peak areas of the SP-2380 chromatograms. To partition the peak area of the co-eluting cpa19:0 and 9,12-18:2 esters, the ratio of the peak areas for the cpa19:0 and cpe19:1 components was determined from the SP-2560 chromatogram, and this ratio was used to calculate the area of the cpa19:0 methyl ester from the SP-2380 chromatographic data. This area was then subtracted from the area of the co-eluting 9,12-18:2 peak to give the corrected area for this ester. To determine relative weights, peak areas were corrected for flame ionization response factor differences, as described in the AOCS method Ce1e 91 (1998).

\subsection{Calculations and cluster analysis}

The total level of saturated and unsaturated fatty acids was calculated from the sum of individual acids of each class. The sum of the cyclopropenoid fatty acids was calculated from the levels of cpe18:1 and cpe19:1, and the total percentage of $\alpha$-oxidized fatty acids was calculated from the levels of cpe18:1, 8,11-17:2, and 8-heptadecenoic acid (8-17:1).

Samples were separated into hierarchical clusters based on the fatty acid results. Cluster analysis was performed with SAS Proc Cluster with Ward's minimum-variance method, which calculates the distance between two clusters as the ANOVA sum of squares.

\section{RESULTS AND DISCUSSION}

Tilia spp. seed oils are composed mostly of 9,1218:2 with lesser amounts of 9-18:1 and palmitic (16:0) acid (Tables 1 and 2), which is similar to the profiles of most Malvaceae seed oils. Most of the expected secondary components were also found in the oil, including myristic (14:0), stearic (18:0), arachidic (20:0), behenic (22:0), lignoceric (24:0), palmitoleic (9-16:1) and cis-vaccenic (11-18:1) acids (Figure 1 ). Small amounts $(0.05$ to $0.1 \%$ ) of heptadecanoic (17:0), 9-heptadecenoic (9-17:1), 9,10-epoxystearic, and vernolic acids were also identified and were included in the analysis. Traces $(<0.05 \%)$ of additional acids were also detected but were not included as their contributions to the distributions were minor.

Cpe18:1 and cpe19:1 were present in all samples analyzed. $T$. amurensis had the highest combined level of these acids at just over $17 \%$, 
Table 1

Fatty acid composition of the seed oils from Tilia spp. (part 1)

\begin{tabular}{|c|c|c|c|c|c|c|}
\hline & $\begin{array}{c}\text { T. americana } \\
\text { (1) }\end{array}$ & $\begin{array}{c}\text { T. amurensis } \\
\text { (1) }\end{array}$ & $\begin{array}{c}\text { T. caucasica } \\
\text { (1) }\end{array}$ & $\begin{array}{c}\text { T. cordata } \\
\text { (1) }\end{array}$ & $\begin{array}{c}\text { T. cordata } \\
\text { (2) }\end{array}$ & $\begin{array}{l}\text { T. cordata } \\
\text { (3) }\end{array}$ \\
\hline $14: 0$ & 0.12 & 0.19 & 0.27 & 0.24 & 0.18 & 0.22 \\
\hline 16:0 & 9.80 & 8.07 & 9.76 & 9.86 & 8.32 & 9.33 \\
\hline $17: 0$ & 0.09 & 0.08 & 0.09 & 0.09 & 0.10 & 0.06 \\
\hline 18:0 & 1.20 & 1.53 & 1.71 & 1.61 & 1.13 & 1.40 \\
\hline 20:0-24:0 & 0.21 & 0.23 & 0.17 & 0.24 & 0.22 & 0.17 \\
\hline $9-16: 1$ & 0.25 & 0.19 & 0.13 & 0.24 & 0.19 & 0.23 \\
\hline $8-17: 1$ & 0.66 & 0.46 & 0.56 & 0.81 & 0.73 & 0.73 \\
\hline $9-17: 1$ & 0.12 & 0.09 & 0.07 & 0.12 & 0.14 & 0.08 \\
\hline 9-18:1 & 17.5 & 15.5 & 21.1 & 20.9 & 22.2 & 21.9 \\
\hline 11-18:1 & 1.43 & 1.16 & 0.89 & 1.42 & 1.29 & 1.38 \\
\hline 11-20:1 & 0.11 & 0.09 & 0.14 & 0.10 & 0.13 & 0.10 \\
\hline $8,11-17: 2$ & 1.26 & 0.97 & 0.80 & 1.14 & 1.11 & 1.05 \\
\hline $9,12-18: 2$ & 53.0 & 52.5 & 52.4 & 45.9 & 49.2 & 51.3 \\
\hline $9,12,15-18: 3$ & 0.74 & 0.97 & 0.67 & 0.87 & 0.92 & 0.72 \\
\hline cpe18:1 & 7.84 & 9.89 & 6.14 & 9.74 & 8.64 & 6.43 \\
\hline cpe19:1 & 4.81 & 7.16 & 4.30 & 5.67 & 4.66 & 4.39 \\
\hline сра19:0 & 0.62 & 0.63 & 0.62 & 0.80 & 0.68 & 0.42 \\
\hline$E A^{c}$ & 0.07 & 0.10 & 0.03 & 0.11 & 0.04 & 0.06 \\
\hline$V A^{c}$ & 0.06 & 0.11 & 0.06 & 0.21 & 0.04 & 0.03 \\
\hline Total cpe ${ }^{c}$ & 12.7 & 17.1 & 10.4 & 15.4 & 13.3 & 10.8 \\
\hline Total sat. $^{c}$ & 11.4 & 10.1 & 12.0 & 12.0 & 10.0 & 11.2 \\
\hline Total unsat. ${ }^{c}$ & 75.1 & 71.9 & 76.8 & 71.5 & 75.9 & 77.5 \\
\hline 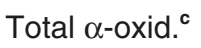 & 9.8 & 11.3 & 7.5 & 11.7 & 10.5 & 8.2 \\
\hline
\end{tabular}

${ }^{a}$ Trace levels of 12:0, 15:0, 21:0, and 23:0 were also detected but were not included in the calculations.

${ }^{b}$ The number in parentheses under a species name indicates the sample number for that species.

${ }^{c} \mathrm{EA}=9,10$-epoxy-18:0; VA = vernolic acid or 12,13-epoxy-9-18:1; Total cpe = total cyclopropenoid fatty acids; Total sat. = total saturated fatty acids; Total unsat. $=$ total unsaturated fatty acids; Total $\alpha$-oxid. $=$ total fatty acids that have undergone $\alpha$-oxidation $=$ cpe $18: 1+8: 17: 1$ $+8,11-17: 2$.

while T. mandshurica and T. tomentosa appeared to have the lowest levels at 5.8-7.1\%. Dihydrosterculic acid (cpa19:0) was also observed in all of the seed oils at levels between 0.4 to $0.9 \%$. In all species evaluated, cpe18:1 was in higher concentration than cpe19:1.

Differences were apparent in the levels of cyclopropenoid fatty acids compared with prior reports. The stability of these acids was a concern in early attempts to measure these components, with both derivatization conditions and instrumentation limitations contributing to the problems. Of the early reports on Tilia spp. seed oils, only Raju and Resier (1966) mention the presence of cyclopropenoid fatty acids in $T$. platyphyllos at a combined level of $3.2 \%$. Significantly greater combined levels (8.3-8.6\%) were found for the two T. platyphyllos samples included in this study (Table 2). This difference might be due to seed sample variation or to complications associated with the thiomethyl derivatization technique used by Raju and Reiser (1966) to stabilize these fatty acids. Degradation of the compounds as methyl esters on early chromatography systems has also been noted (Coleman, 1970; Fisher and Schuller, 1981), which may account for the lack of information about these acids in several of the early Tilia reports. These chromatographic problems, however, appear to have been largely eliminated by the development of more inert chromatographic inlets and capillary columns (Fisher and Schuller, 1981). The absence of information regarding these acids in the relatively recent report by Küsmenoğlu and Toker (1998) may have stemmed from the use of an acid-based esterification method, as cyclopropenoid acids are unstable in acid (Raju and Reiser, 1966; Coleman, 1970). Alternatively, the chromatogram shown by Küsmenoğlu and Toker (1998) appears to have a few unidentified components that may have represented these acids. 
Table 2

Fatty acid composition of the seed oils from Tilia spp. (part 2) $)^{a, b}$

\begin{tabular}{|c|c|c|c|c|c|c|}
\hline & $\begin{array}{c}T . \\
\text { mandshurica } \\
(1)\end{array}$ & $\begin{array}{c}T . \\
\text { platyphyllos } \\
\text { (1) }\end{array}$ & $\begin{array}{c}T . \\
\text { platyphyllos } \\
(2)\end{array}$ & $\begin{array}{c}\text { T. tomentosa } \\
\text { (1) }\end{array}$ & $\begin{array}{c}\text { T. tomentosa } \\
\text { (2) }\end{array}$ & $\begin{array}{c}\text { T. tomentosa } \\
\text { (3) }\end{array}$ \\
\hline $14: 0$ & 0.11 & 0.23 & 0.18 & 0.08 & 0.11 & 0.11 \\
\hline 16:0 & 8.09 & 8.13 & 8.49 & 8.75 & 8.46 & 8.72 \\
\hline $17: 0$ & 0.08 & 0.07 & 0.09 & 0.07 & 0.08 & 0.08 \\
\hline 18:0 & 1.53 & 2.15 & 1.45 & 1.50 & 1.72 & 1.83 \\
\hline $20: 0-24: 0$ & 0.20 & 0.20 & 0.18 & 0.19 & 0.19 & 0.18 \\
\hline $9-16: 1$ & 0.13 & 0.11 & 0.12 & 0.12 & 0.10 & 0.13 \\
\hline 8-17:1 & 0.49 & 0.69 & 0.86 & 0.56 & 0.64 & 0.71 \\
\hline $9-17: 1$ & 0.10 & 0.05 & 0.09 & 0.07 & 0.07 & 0.07 \\
\hline $9-18: 1$ & 16.6 & 18.0 & 21.1 & 18.4 & 20.0 & 20.3 \\
\hline 11-18:1 & 1.11 & 0.76 & 0.89 & 1.02 & 0.90 & 1.00 \\
\hline 11-20:1 & 0.14 & 0.20 & 0.20 & 0.13 & 0.17 & 0.13 \\
\hline $8,11-17: 2$ & 0.84 & 1.25 & 1.25 & 0.99 & 0.94 & 1.19 \\
\hline $9,12-18: 2$ & 60.0 & 58.1 & 54.8 & 59.3 & 57.8 & 58.1 \\
\hline $9,12,15-18: 3$ & 1.06 & 0.84 & 0.72 & 0.73 & 0.56 & 0.77 \\
\hline cpe18:1 & 5.80 & 5.50 & 5.65 & 4.34 & 4.82 & 3.68 \\
\hline cpe19:1 & 2.65 & 2.84 & 2.93 & 2.73 & 2.40 & 2.15 \\
\hline сpa19:0 & 0.98 & 0.68 & 0.87 & 0.91 & 0.82 & 0.78 \\
\hline$E A^{c}$ & 0.05 & 0.04 & 0.05 & 0.05 & 0.07 & 0.07 \\
\hline$V^{c}$ & 0.09 & 0.06 & 0.08 & 0.10 & 0.13 & 0.04 \\
\hline Total cpe ${ }^{c}$ & 8.5 & 8.3 & 8.6 & 7.1 & 7.2 & 5.8 \\
\hline Total sat. $^{c}$ & 10.0 & 10.8 & 10.4 & 10.6 & 10.6 & 10.9 \\
\hline Total unsat. $^{c}$ & 80.5 & 80.0 & 80.0 & 81.3 & 81.2 & 82.4 \\
\hline 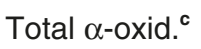 & 7.1 & 7.4 & 7.8 & 5.9 & 6.4 & 5.6 \\
\hline
\end{tabular}

${ }^{a}$ Trace levels of 12:0, 15:0, 21:0, and 23:0 were also detected but were not included in the calculations.

${ }^{\mathrm{b}}$ The number in parentheses under a species name indicates the sample number for that species.

${ }^{\mathrm{c}} \mathrm{EA}=$ 9,10-epoxy-18:0; VA = vernolic acid or 12,13-epoxy-9-18:1; Total cpe = total cyclopropenoid fatty acids; Total sat. = total saturated fatty acids; Total unsat. $=$ total unsaturated fatty acids; Total $\alpha$-oxid. $=$ total fatty acids that have undergone $\alpha$-oxidation $=$ cpe $18: 1+8: 17: 1$ $+8,11-17: 2$.

Two of the early reports on Tilia spp. seed oils noted significant levels of short chain fatty acids (Cristea and Stanescu, 1967; Küsmenoğlu and Toker, 1998). Cristea and Stanescu (1967) reported that $11.6 \%$ of the seed oil fatty acids of $T$. platyphyllos are a combination of caprolic, caprylic, capric, and lauric (12:0) acids. Smaller but still significant levels of these acids were also noted in the seed oils of $T$. argentea (a synonym of $T$. tomentosa) and $T$. silvestris (most likely $T$. cordata). Kusmenoğlu and Toker (1998) have also reported that $T$. tomentosa (reported as $T$. argentea), $T$. platypyllos and $T$. rubra contain short-chain acids, corresponding to between 12.5 and $32.9 \%$ of the fatty acids present. In contrast, the report by MrukŁuczkiewicz (1976) on T. cordata seed oil does not mention these acids.

In this work, shorter-chain fatty acids were not present at any significant level (only 12:0 was detected and it was measureable in only a few samples at around $0.01 \%$ ). Because it was possible for these acids to be present in free form and therefore not methylated by base catalysis, $\mathrm{BF}_{3}$-methanol esterification was used to test for their presence in a few samples ( $T$. cordata, $T$. platypyllos, and $T$. tomentosa). This procedure, however, did not reveal any additional levels of these shorter-chain components. Our suspicion is that the methylation conditions used in these early reports may have resulted in the formation of artifacts. These smaller fragments would elute from the chromatography phase before the longerchain esters and were likely accounted for as low molecular weight esters. Alternatively, seed quality may have been low, and oil degradation may have contributed to the profiles.

Two additional fatty acids were also observed in the chromatograms (Figures 1 and 2). 8-17:1 
was present at levels between 0.5 and $0.9 \%$, and $8,11-17: 2$ was present at levels between 0.8 and $1.3 \%$; their identities were confirmed by mass spectrometric methods previously described (Dowd, 2012). Biochemically, these acids appear to form by one-carbon oxidation of the oil's major unsaturated components, i.e., 9-18:1 and 9,1218:2. The maximum level of these $\alpha$-oxidation products was $\sim 2.1 \%$ for one of the $T$. platyphyllos samples. This is comparable to the level of these acids recently reported in the seed oils of Thespesia populnea (Dowd, 2012), another Malvaceae plant but from the Malvoideae subfamily.

Fatty acid profiles have been used to identify adulteration in vegetable oils (Dourtoglou et al., 2003) and as an aid to identify microbial species (Slabbinck et al., 2009). A clustering analysis was conducted on the species analyzed in this study to see how closely the fatty acid profiles might relate to known taxonomical relationships among Tilia spp. plants. As for many plant genera, the taxonomy of the Tilia genus is complicated and is not fully settled (Engler, 1909; Vassiljev, 1971; Clark, 2009). While the results of the clustering analysis show elements of agreement with these classification schemes (Figure 3), they are not in full accord. For example, while the individual $T$. tomentosa and $T$. cordata samples were closely grouped (Figure $3)$, the two samples of $T$. platyphyllos were not, having one representative in each of the two major dendographic branches. Also, the T. tomentosa and $T$. mandshurica samples, which represent the Astrophilyra section of the genus in both the Engler (1909) and Vassiljev (1971) classification schemes, form a major cluster branch, while the other species, which represent the Anastraea section of the genus, form a companion branch. Not fitting the pattern, however, are the T. americana and $T$. amurensis samples, which cluster closely based on their fatty acid profiles, but are separated into the two above mentioned taxonomical sections. Further analysis of the finer branches reveals additional differences. The fact that differences exist

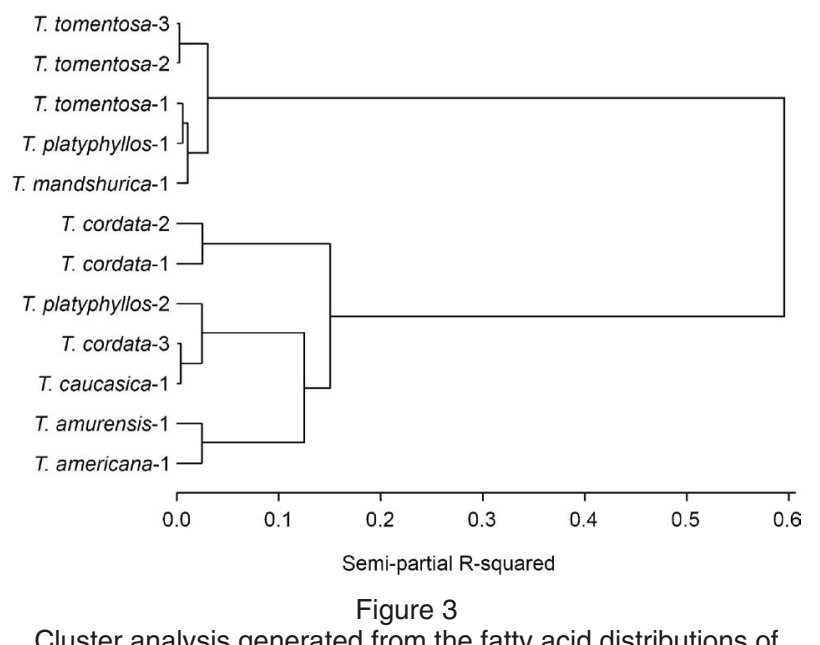

Cluster analysis generated from the fatty acid distributions of several Tilia spp. seed oils. between the clustering analysis and the proposed taxonomical relationships is not surprising, given that plant fatty acid profiles are known to be influenced by environment, and this factor has not been accounted for in this modest sampling of seeds.

\section{CONCLUSIONS}

Tilia spp. seed oils contain significant levels of cyclopropenoid fatty acids (6-17\%). They also contain minor levels of unsaturated heptadecyl fatty acids, which have not been previously noted among the oil components of this plant genus. Short-chain fatty acids mentioned in prior reports were not observed in this study.

\section{ACKNOWLEDGEMENTS}

The authors thank Michael Santiago (ARS) for help with the Spanish abstract translation, Debbie Boykin (ARS) for help with the clustering analysis, and Gary List and Joseph Montalvo (ARS) for reviewing the report prior to publication.

\section{REFERENCES}

Alverson WS, Whitlock BA, Nyffeler R, Bayer C, Baum DA. 1999. Phylogeny of the core Malvales: evidence from $n d h F$ sequence data. Am. J. Bot. 86, 14741486.

Bao X, Katz S, Pollard M, Ohlrogge J. 2002. Carbocyclic fatty acids in plants: biochemical and molecular genetic characterization of cyclopropane fatty acid synthesis of Sterculia foetida. Proceed Nat. Acad. Sci. 99, 7172-7177.

Bayer C, Fay MF, de Bruijn AY, Savolainen V, Morton CM, Kubitzki K, Alverson WS, Chase MW. 1999. Support for an expanded family concept of Malvaceae within a recircumscribed order Malvales: a combined analysis of plastid atpB and rbcL DNA sequences. Bot. J. Linn. Soc. 129, 267-303.

Clark JY. 2009. Neural networks and cluster analysis for unsupervised classification of cultivated species of Tilia (Malvaceae). Bot. J. Linn. Soc. 159, 300-314.

Coleman EC. 1970. An evaluation of five methods for the quantitative determination of cyclopropenoid fatty acids. J. Assoc. Off. Anal. Chem. 53, 1209-1213.

Cristea E, Stanescu L. 1967. Phytochemical investigations of Tilia fruit. I. Chromatographic analysis of the fatty acids in the oil extracted from Tilia fruit (in Romanian). Framacia (Bucharest) 15, 695-698.

Dourtoglou VG, Dourtoglou Th, Antonopoulos A, Stefanou E, Lalas S, Poulos C. 2003. Detection of olive oil adulteration using principal component analysis applied on total and regio FA content. J. Am. Oil Chem. Soc. 80, 203-208.

Dowd, MK. 2012. Identification of the unsaturated heptadecyl fatty acids in the seed oils of Thespesia populnea and Gossypium hirsutum. J. Am. Oil Chem. Soc. 89, 1599-1609.

Engler V. 1909. Monograph of the genus Tilia (in German). Druck von W. G. Korn., Breslau, Germany. 
Fisher GS, Schuller WH. 1981. Gas chromatographic analysis of cyclopropenoid fatty acids in cottonseed oils. J. Am. Oil Chem. Soc. 58, 943-946.

Küsmenoğlu S, Toker G. 1998. Fatty acid composition of Tilia fruit oils. Acta Pharm. Turc. 40, 121-123.

Mruk-Łuczkiewicz A. 1976. Physiochemical studies of the oil from seeds and fruits of Tilia cordata Mill (in Polish). Ann. Acad. Med. Gedanensis 6, 147-154.

Official Method Ce 1e-91. 1998. In D. Firestone (Ed.), Official Methods and Recommended Practices of the AOCS, $5^{\text {th }}$ edition, AOCS Press, Champaign, IL USA.

Raju PK, Reiser R. 1966. Gas-liquid chromatographic analysis of cyclopropene fatty acids. Lipids 1, 10-15.
Slabbinck B, de Baets B, Dawyndt P, de Vos P. 2009. Toward large-scale FAME-based bacterial species identification using machine learning techniques. Syst. Appl. Microbiol 32, 163-176.

Vassiljev I. 1971. Conspectus of the genus Tilia L (in Russian). Nov. Sist. Vyssh. Rast. 8, 202-208.

Yano I, Morris LJ, Nichols BW, James AT. 1972. The biosynthesis of cyclopropane and cyclopropene fatty acids in higher plants (Malvaceae). Lipids 7, 35-45.

Recibido: 20/9/12 Aceptado: $16 / 1 / 13$ 